one of the enantiomorphously related configurations; all the albumins are lævo-rotatory, all the starches and sugars are derived from dextro-glucose. Since Fischer's work teaches us that none of the sugars derived from lævoglucose are fermentable by yeast, it would seem to follow as a legitimate conclusion that, whilst $d$-glucose is a valuable food-stuff, we should be incapable of digesting its enantiomorphously related isomeride, $l$-glucose. Humanity is therefore composed of dextro-men and dextro-women. And just as we ourselves would probably starve if provided with nothing but food enantiomorphously related to that to which we are accustomed, so, if our enantiomorphously related isomerides, the lævo-men, were to come among us now, at a time when we have not yet succeeded in preparing synthetically the more important food-stuffs, we should be unable to provide them with the food necessary to keep them alive.

\section{CHLORINE SMELTING, WITH ELECTROLYSIS}

A PAPER on chlorine smelting with electrolysis was read by Mr. Swinburne at the first meeting of the Faraday Society; as the process described in the paper is of considerable interest, and may one day be of great importance, we give a brief abstract of the paper below.

The process is one for the treatment of complex sulphide ores, such, for example, as the Broken Hill slimes, and is divided into three stages as follows:-(I) the treatment of the ores with hot chlorine, whereby the metals are all obtained as chlorides; (2) the treatment of the mixed chlorides by substitution until finally all the chlorine is combined with zinc; and (3) the electrolysis of the zinc chloride 10 extract the zinc and recover the chlorine. The first stage of the process is carried out by blowing hot chlorine into the crushed ore in a "transformer"; the essential feature is to avoid the formation of chloride of sulphur.

This involves a careful regulation of temperature and of the rate of feed of the ore; the temperature can be easily regulated by the rate of feed of the ore and chlorine as the reaction evolves a great deal of heat, and the transformer is entirely self-heating. Advantage can be taken of the composition of the ore, as some of the metals have a greater heat of reaction than others; if necessary, a mixture of ores of different compositions can be made so as to give a satisfactory working material. The sulphur is set free and condensed. At the end of a charge the ore feed is stopped, and the excess of sulphides converted to chlorides, after which the fused chlorides are drawn off and dissolved; the gangue having been separated by filtration, the second part of the process begins. This naturally depends on the composition of the ore; lead, silver, and gold are separated with the gangue, and after drying are fused first with lead, which extracts the silver and gold, and then with zinc, which gives lead and zinc chloride, the former practically pure. The filtrate is treated with spongy copper to separate lead and silver, and then with zinc to take out the copper. Iron, manganese, and zinc chlorides are left; the iron is chlorinated up to the ferric state, and precipitated as ferric hydrate by zinc oxide, and further chlorination in presence of the zinc oxide throws down the manganese as peroxide. There is thus left only zinc chloride in solution, and this is evaporated down and fused. To it is added the fused chloride from the lead substitution, and the whole is electrolysed in vats made of iron lined with fire-brick. The heating is internal; the current and the chloride soaking into and solidifying in the fire-brick gives really a vat with zinc chloride walls. Vats taking 3000 amperes have been in use, but these are small, and 10,000 ampere vats are to be tried; the pressure required is less than four volts. The result of the process is pure zinc and chlorine ready for chlurination of fresh ore.

It will be seen that the chief merits of the process are its comprehensiveness, its cyclical nature, and the fact that it turns out pure metals. Obviously it is suited, with only slight modifications, for the treatment of a great variety of ores. The chlorine simply goes round and round; apart from leakage, which, as Mr. Swinburne says, if it would show on the balance sheet would make the works uninhabit- able, chlorine can only be lost as chloride of sulphur (a source of loss the inventors claim to have overcome), and as oxychlorides formed in the iron separation and in evaporation of the zinc chloride, neither of great importance if care be taken. The works therefore simply take in ore and electrical energy and turn out metals, sulphur, and gangue. Mr. Swinburne enters at some length into the question of cost, but space does not permit of our following him here; we have said enough to indicate the interesting character of the paper, to which those more specially interested may be referred for further details.

M. S.

\section{THE ROYAL INSTITUTE OF PUBLIC} HE ALTH.

THE annual congress of the Royal Institute of Public Health was held at Liverpool, July $15-21$, under the presidency of the Earl of Derby. The sections met in the various departments of the University College, and were thus closely associated and readily accessible. The proceedings were opened by an interesting address from the Ear of Derby, in which he directed attention to the considerable progress in sanitation that had been made by many ancient civilisations. The Harben medals for 1901 and 1902 were then presented to Sir Charles Cameron and Prof. W. R. Smith.

A combined conference of the preventive medicine and municipal hygiene sections discussed the subject of tuberculosis, and Dr. Nathan Raw read a paper upon "The Prevention of Consumption in Large Cities," in which he expressed the opinion that consumption is frequently conveyed to children by milk from tuberculous cows, though patients in the advanced stage are the greater source of danger to the community. He suggested as means for controlling the disease (I) the establishment of a central office where consumptives might seek advice; (2) the erection of a municipal sanatorium which, for Liverpool, should contain ron beds, and be within the reach of any needy citizen; and (3) the foundation of a hospital for the poor for at least roo incurable cases. Several other papers dealing with tuberculosis were also contributed; one, by Mr. McLauchlan Young, who summarised the experiments performed by Prof. Hamilton and himself upon the communicability of bovine tuberculosis to man, and expressed the opinion that there could be little doubt that human tubercle can be readily inoculated upon bovines; another, by Drs. Dean and Todd, upon the communicability of human tuberculosis to the pig, in which the six animals experimented upon were all infected with the human bacillus. Thus there is already an accumulation of evidence against the view expressed by Koch at the Tuberculosis Congress of I9or, that bovine tuberculosis is probably not communicable to man.

In the section of bacteriology and comparative pathology, the president, Prof. Boyce, F.R.S., in his opening address directed attention to the connection between abstract research and the good of the community, instancing the value of bacteriological research to practical medicine, to the farmer, to the water engineer, and to the oyster merchant. A paper by Dr. Savage upon " A Uniform Method of Procedure for the Bacterioscopic Examination of Water," evoked an interesting discussion. He considered the subject under four headings:-(I) the methods of collection and transmission of the samples; $(2)$ the data which it is desirable to ascertain; (3) the processes and procedures of the examination; and (4) the significance to be attached to the results obtained. It was ultimately resolved to form a committee to consider whether it might not be possible to systematise the methods, \&c., to be used for the bacteriological examination of water.

Another important discussion, upon " the nature and significance of the pseudo-diphtheria bacillus," was opened by Dr. Cobbett, who expressed the opinion that this organism has nothing whatever to do with the true diphtheria bacillus. Prof. Hewlett stated that he was not yet convinced that the two organisms had no connection, and directed attention to several points of similarity between the two. Several medical officers of health held that, whether the two organisms had any connection or no, the pseudo-bacillus sometimes produced a diphtheritic condition. It is im-

No. I 760 , voL. 68] 
possible to summarise the number of important papers that were read upon the housing question, child-study, port sanitation, and other subjects. Dr. Hope, the local secretary, is to be congratulated upon the arrangements made, and it is hardly necessary to add that Liverpool extended a hearty welcome to the delegates and members of the congress.

R. T. Hewlett.

\section{UNIVERSITY AND EDUCATIONAL INTE LLIGENCE.}

A RERORT on the scheme for the establishment, in London, of an institute for advanced technological instruction and research, recently put forward by Lord Rosebery, was presented to the London County Council on Tuesday. It will be remembered that the offer was made of land, buildings, and equipment required for such an institution to the value of $500,000 l$, with the promise to secure other funds for both capital outlay and maintenance, provided that the council would express, in general terms, its willingness to contribute, when the buildings were equipped and ready to be opened, a sum of $20,000 l$. a year towards the maintenance of the educational work. In referring to these proposals in our issue of July 2 (p. 203), we pointed out the importance of coordinating the work of such an institute with that of the University of London, and expressed the opinion that the development of both was a national concern, and ought not to depend upon the contributions of the County Council. We are glad to see that the committee of the council appointed to consider the scheme regard substantial assistance from the State as an essential condition of support, and think the council should not lend any encouragement to the idea that the whole of the cost of maintenance could be provided from London sources. The following recommendations of the committee were adopted by the council at 'Tuesday's meeting:-(a) That the council expresses its high appreciation of the important proposal contained in Lord Rosebery's letter, and would cordially welcome the establishment of further provision in London for advanced technological teaching and research. (b) That the council, in response to the request contained in Lord Rosebery's letter, places on record its opinion that, when the land, buildings, and equipment for the proposed additional technological teaching and research are provided to a value of not less than $500,000 l$. the council will be well advised to contribute, out of the monevs annually placed at its disposal under the Local Taxation (Customs and Excise) Act of 1890 , a sum not exceeding $20,000 l$. per annum towards such part of the work as falls within the statutory definition of technical education, subject to the following conditions:-(I) That a scheme be prepared to the satisfaction of the council for the constitution of the governing body and the adequate representation of the council thereon; (2) that financial arrangements adequate to the whole maintenance of the proposed work are made to the satisfaction of the council; (3) that, in view of the national scope and utility of the proposed work, substantial contributions towards maintenance be made from funds of a national character; (4) that due provision be made in the scheme to prevent overlapping and secure coordination of the work already carried on by the university colleges, polytechnics, and other science and technological institutions, and the proper connection of the whole with the university; (5) that a sufficient number of scholarships, including free places, be placed at the disposal of the council; (6) that it be considered whether other counties and boroughs should not be invited to contribute towards the maintenance, receiving in return the right to send their picked scholars for instruction under the proposed scheme.

THE Board of Education have issued new regulations for the instruction and training of pupil teachers and students in training colleges. In a preface by Mr. Morant it is stated that the "regulations are intended to secure for the pupil teacher a more complete and continuous education, and to make the period of service in an elementary school a time of probation and training rather than of too early practice in teaching." Pupil teachers admitted on and after August I, 1904, must not be under sixteen years of No. I 760 , vor. 68$]$ age, except in rural districts, where the limit will be fifteen. After August I, 1905, pupil teachers will not be permitted to serve in a public elementary school more than half the time the school is open, and they will be required to receive half-time instruction in an approved pupil teacher centre throughout their engagement. The Board of Education desires to encourage plans for educating pupil teachers with other scholars, and urges local educational authorities to arrange, by means of an adequate scholarship system or otherwise, that all the best candidates for pupil teacherships, whether boys or girls, should receive a sound general education in a secondary school, with schoolfellows intended for other careers, before they commence service in any capacity in an elementary school. There is already in existence a number of well-equipped and well-staffed pupil teacher centres, the best of which have more than fulfilled the purpose for which they were originally recognised by the Board. The new regulations should assist in developing corporate school life in such centres, and also in improving other less satisfactory central classes; they mark a very decided step in advance, and show an exact appreciation of the shortcomings of the pupil teacher system as it has existed until now.

A SCHEME whereby pupils in schools in different parts of the Empire may be put in communication with one another, with the view of exchanging observations, specimens and ideas, has been drawn up by the League of the Empire, and promises to be of great educational value. The committee recommends that linked-schools and members should first exchange maps of their respective districts, and where possible, photographs or drawings of their houses, of the school house, grounds and surroundings. It is suggested that nature calendars should be kept, essays written on common trees or other plants, and notes made on the habits of birds or other animals, or on industrial processes or natural products in the neighbourhood of the schools-all with the view of exchanging them with schools in other parts. Personal observations are to be insisted upon, so that the descriptions will be twice blessed-those who make the observations by exercising the best of their faculties, and those who receive the results by gaining knowledge of natural conditions beyond their individual view. Specimens are also to be exchanged for school museums. Already there are nearly two thousand members in correspondence all over the Empire exchanging specimens and letters, and the number will doubtless be greatly increased. Particulars of the scheme may be obtained from Mrs. Ord Marshall, hon. secretary of the central committee, in Dartmouth Street, Victoria Street, London, S.W.

To prevent misunderstanding, Mr. C. McDermid, secretary of the Bessemer Memorial Fund, has issued a letter in which the relationship between the scheme for the Bessemer memorial and that put forward by Lord Rosebery is described. The persons responsible in each case have been in close consultation throughout, but the two schemes will continue for the present to be directed separately, though they will be controlled by joint trustees. For the purposes of the advanced metallurgical training and specialised research works which are to form the Bessemer memorial, it is proposed that London shall be regarded as the centre for the metallurgy of copper, silver, gold, \&c., Sheffield as the centre for steel, and Birmingham as the centre for cast and wrought iron and alloys. It is intended that the post-graduate scholarships shall, in part, be international. It is hoped that the committee will be able to submit the complete scheme in October.

DR. W. Schlich, principal professor of forestry in the Royal Indian Engineering College, Coopers Hill, has been appointed honorary professor of forestry at the Royal Agricultural College, Cirencester. Mr. McClellan, jun., who was recently appointed professor of forestry and estates management at the college, has, during the past four months, been gaining experience of continental forestry, and with Dr. Schlich has made a six weeks' tour through specially interesting forest districts in Germany.

Mr. H. W. Richards has been appointed principal of the Brixton Technical Institute of the London Technical Education Board. The Board has made the following appointments in connection with the Paddington Technical 